\title{
Selective enhancement of urinary organic mercury excretion by D-penicillamine
}

\author{
NOBUO ISHIHARA ${ }^{1}$, SHOJI SHIOJIMA ${ }^{2}$, AND TSUGUYOSHI SUZUKI ${ }^{3}$ \\ Department of Hygiene, Tohoku University School of Medicine' ${ }^{1}$ Tohoku Rosai Hospital' ${ }^{2}$, \\ and Department of Public Health, Tohoku University School of Medicine, ${ }^{3}$ Sendai, Japan
}

\begin{abstract}
Ishihara, N., Shiojima, S., and Suzuki, T. (1974). British Journal of Industrial Medicine, 31, 245-249. Selective enhancement of urinary organic mercury excretion by D-penicillamine. This report deals with the study of a patient who was suspected of having mercury vapour poisoning and was treated with D-penicillamine.

D-penicillamine by mouth enhanced the urinary excretion of organic but not inorganic mercury. It was considered that $\mathrm{D}$-penicillamine was ineffective because at a relatively low dose level of inorganic mercury exposure most inorganic mercury was tightly bound to sites of great affinity for mercury in tissues and resistant to replacement with D-penicillamine. On the contrary, organic mercury was considered to be easily replaced with D-penicillamine.

The need to study further the different nature of tissue binding between inorganic and organic mercury is discussed.
\end{abstract}

It is well known that peroral administration of Dpenicillamine is effective for the enhancement of urinary mercury excretion not only in inorganic mercury poisoning (Aposhian, 1958; Smith and Miller, 1961) but also in methylmercury poisoning (Tsubaki and Shirakawa, 1968; Suzuki and Yoshino, 1969). However, in a case of methylmercury poisoning no effective enhancement was observed (Suzuki and Yoshino, 1969). It was suggested that this was due to the long time interval between the end of methylmercury exposure and the administration of D-penicillamine.

Recently, selective measurement of inorganic and organic mercury became applicable to the small amount of mercury in the urine, but no account has been found of the selective or differential effect of D-penicillamine on urinary inorganic and organic mercury excretion.

This is a report of the results of selective measurement of inorganic and organic mercury in hair and urine of a patient who worked for about eight years in the operation-room of an electric news-board and was suspected of having mercury vapour poisoning. He was treated twice with D-penicillamine.
Selective measurement of urinary mercury was carried out by the method described by Magos (1971). The method for hair was essentially the same as that for the whole homogenate of a mouse (Magos, 1971). The actual procedure was as follows: The hair was cut into small pieces weighing 30 or $60 \mathrm{mg}$ and boiled in $1.5 \mathrm{ml}$ of $40 \%$ $\mathrm{NaOH}$ (containing $1 \%$ cysteine-HCl) for 20 minutes. After boiling, the whole sample was transferred to a reaction vessel with about $5 \mathrm{ml}$ of distilled water for cold atomic absorption spectroscopy.

Urine was collected for each 24-hour interval, cysteine$\mathrm{HCl}$ was added, and it was stored in a refrigerator until measurement.

The reagents, especially cysteine- $\mathrm{HCl}$, were checked for contamination with mercury at every lot number.

To eliminate the possibility of inorganic mercury bound or complexed with D-penicillamine being measured as organic mercury, $100 \mathrm{ng}$ of inorganic mercury (sublimate solution) in distilled water and $0.4 \%$ D-penicillamine solution was measured for comparison. No significant difference was found.

\section{Case report}

A Japanese man aged 58 years worked from 1964 to 1972 
as one of two operators of an electric news-board. In the operating room, a considerable amount of metallic mercury was used as the electrode. In 1964 the inspector of Miyagi Labour Standard Office reported the atmospheric mercury concentration as 0.2 to $1.0 \mathrm{mg} / \mathrm{m}^{3}$. His usual working period in the operating room was about 10 minutes per day, but when the machine was out of order it was several hours.

In September 1972 he began to complain of restlessness, tremor, salivation, headache, disturbed sleep, giddiness, and thirst, and visited a general practitioner near his workplace. The doctor, after about one month's ineffective treatment, suspected that the symptoms were due to mercury poisoning. However, the patient left his job in October 1972, because the advertising company owning the electric news-board decided to stop this news service, and the facilities for the electric news-board were removed. He was sent to Tohoku Rosai Hospital on 9 November 1972. The above-mentioned symptoms persisted, but no abnormalities sufficient to explain the symptoms were found. Urinary mercury concentration was $31 \cdot 1 \mu \mathrm{g} / 1$ on a spot sample of urine on 5 December 1972. This value of urinary mercury content was certainly above the upper limit in Japanese without any occupational exposure to mercurials (Suzuki and Shishido, 1974) but not high enough for diagnostic evidence of mercury poisoning. Symptomatically, the most probable diagnosis was considered to be mercury vapour poisoning. No abnormality was found in the liver or kidney functions. In January 1973 he was again admitted to hospital. The symptoms still persisted except for the disappearance of salivation. The urinary mercury concentration was $65.4 \mu \mathrm{g} /$ day for inorganic mercury and $8 \cdot 1 \mu \mathrm{g} /$ day for organic mercury in the 24-hour urine specimen of 22 January 1973, when about three months had elapsed since the end of mercury vapour exposure. This value of urinary inorganic mercury concentration strongly indicated that the symptoms were due to poisoning by mercury vapour.
D-penicillamine was given orally to this patient in a daily dose of $800 \mathrm{mg}$ for four days from 23 to 26 January and from 1 to 4 October in 1973. At the second administration of D-penicillamine (October 1973) the only symptom remaining was tremor. The collection of urine was started on the day before the administration and was continued for three or four days after it.

\section{Results}

Effects of D-penicillamine on urinary excretion of mercury

At the first trial D-penicillamine enhanced the excretion of total and organic mercury but at the second trial only that of organic mercury (Tables 1 and 2). The levels of urinary mercury on the days without D-penicillamine fell during the time between the two trials. From a rough estimate, the levels of inorganic, organic, and total mercury at the second trial were about one quarter of those at the first trial.

In the results mentioned above it was quite obvious that the effect of D-penicillamine was selective for organic mercury excretion in this patient, but a general conclusion on the selective effect of D-penicillamine should be reserved until it is clear whether the same effect on mercury excretion is produced in other workers exposed to mercury vapour or other mercurials.

Apart from the effect of D-penicillamine on urinary mercury excretion, it was astonishing to note that the level of urinary organic mercury on the days without D-penicillamine was much higher than that observed in persons without any particular exposure to mercurials, which is about $1.0 \mu \mathrm{g} / \mathrm{l}$ on average (Suzuki and Shishido, 1974). The patient had been occupationally exposed to mercury vapour and we

TABLE 1

Effects of D-Penicillamine at the First Trial

\begin{tabular}{|c|c|c|c|c|}
\hline Date & Inorganic $\mathrm{Hg}(\mu \mathrm{g} /$ day $)$ & Organic $\mathrm{Hg}(\mu \mathrm{g} /$ day $)$ & Total $\mathrm{Hg}(\mu \mathrm{g} /$ day $)$ & Administration of $D$-penicillamine \\
\hline $\begin{aligned} \text { January } 22 & \ldots \\
23 & \ldots \\
24 & \ldots \\
25 & \ldots \\
26 & \ldots \\
27 & \ldots \\
28 & \ldots \\
29 & \ldots\end{aligned}$ & $\begin{array}{r}65 \cdot 4 \\
102 \cdot 5 \\
56 \cdot 4 \\
105 \cdot 0 \\
112 \cdot 0 \\
79 \cdot 0 \\
41 \cdot 9 \\
81 \cdot 2\end{array}$ & $\begin{array}{r}8 \cdot 1 \\
21 \cdot 0 \\
37 \cdot 6 \\
29 \cdot 9 \\
40 \cdot 6 \\
10 \cdot 5 \\
12 \cdot 0 \\
10 \cdot 1\end{array}$ & $\begin{array}{r}73 \cdot 5 \\
123 \cdot 5 \\
94 \cdot 0 \\
134 \cdot 9 \\
152 \cdot 6 \\
89 \cdot 5 \\
53 \cdot 9 \\
91 \cdot 3\end{array}$ & $\begin{array}{l}- \\
+ \\
+ \\
+ \\
+ \\
- \\
-\end{array}$ \\
\hline $\begin{array}{c}\text { Average of days } \\
\text { with } \\
\text { D-penicillamine.. } \\
\text { Average of other } \\
\text { days .. } \quad . .\end{array}$ & $\begin{array}{c}94.0\rceil_{\mathrm{ns}} \\
66.9 \mathrm{~J}\end{array}$ & $\begin{array}{l}32 \cdot 3]_{* *} \\
10 \cdot 2 \mathrm{~J}\end{array}$ & $\begin{array}{r}126 \cdot 3\}_{*} \\
77 \cdot 1 \mathrm{~J}\end{array}$ & \\
\hline
\end{tabular}

ns $=$ not significant $;{ }^{*} \mathrm{P}<0.05{ }^{* *} \mathrm{P}<0.01$ (by analysis of variance)

Total mercury is the value obtained by the addition of the values of inorganic and organic mercury

Figures in the table are the average of double measurements 
TABLE 2

Effects of D-Penicillamine at the Second Trial

\begin{tabular}{|c|c|c|c|c|}
\hline Date & Inorganic $\mathrm{Hg}(\mu \mathrm{g} /$ day $)$ & Organic $\mathrm{Hg}(\mu \mathrm{g} /$ day $)$ & Total $\mathrm{Hg}(\mu \mathrm{g} / \mathrm{day})$ & Administration of D-penicillamine \\
\hline $\begin{array}{lrl}\text { September } & 30 & \ldots \\
\text { October } & 1 & \ldots \\
& 2 & \ldots \\
3 & \ldots \\
4 & . . \\
5 & . . \\
6 & . . \\
7 & . . \\
8 & . .\end{array}$ & $\begin{array}{r}12 \cdot 4 \\
20 \cdot 8 \\
16 \cdot 5 \\
19 \cdot 4 \\
17.9 \\
11.9 \\
6.9 \\
39 \cdot 5 \\
12 \cdot 6\end{array}$ & $\begin{array}{l}2 \cdot 9 \\
7 \cdot 9 \\
7 \cdot 7 \\
8 \cdot 3 \\
7 \cdot 5 \\
1 \cdot 9 \\
1 \cdot 4 \\
4 \cdot 1 \\
1 \cdot 8\end{array}$ & $\begin{array}{r}15 \cdot 3 \\
28 \cdot 7 \\
24 \cdot 2 \\
27 \cdot 7 \\
25 \cdot 4 \\
13 \cdot 8 \\
8 \cdot 3 \\
43 \cdot 6 \\
14 \cdot 4\end{array}$ & $\begin{array}{l}- \\
+ \\
+ \\
+ \\
+ \\
- \\
- \\
-\end{array}$ \\
\hline 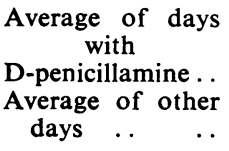 & $\begin{array}{c}18 \cdot 7\rceil_{\mathrm{ns}} \\
16 \cdot 7 \mathrm{~J}\end{array}$ & $\begin{array}{l}7 \cdot 9\}^{* *} \\
2.4\end{array}$ & $\begin{array}{c}26 \cdot 5) \\
\mathrm{ns} \\
19 \cdot 1 \mathrm{~J}\end{array}$ & \\
\hline
\end{tabular}

TABLE 3

Mercury Content in the Hair from Various Parts of the Body

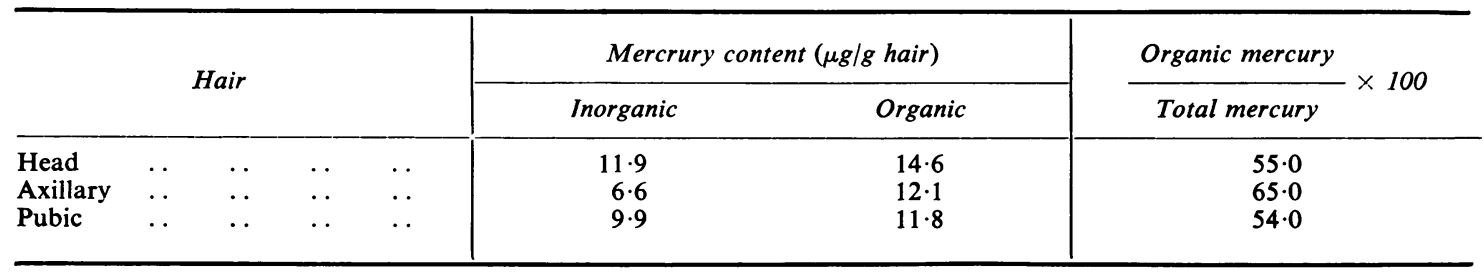

Figures are the average of five measurements

had no evidence of exposure to organic mercury compounds in his history. It was therefore necessary to consider the patient's daily consumption of fish as the main source of organic mercury. The actual diet has not been checked, but he stated that he was very fond of eating fish but did so less than once a day.

\section{Mercury content in hair}

Hair cut from three parts of the body in January 1973 was measured (Table 3). Mercury content in head hair was the highest among these samples, as Skerfving (1974) reported in Swedes consuming contaminated fish. The amount of organic mercury was 54 to $65 \%$ of total mercury, similar to the results reported by Miyama, Asakura, Takemoto, and Suzuki (1973) on the hair of workers exposed to mercury vapour. The level of inorganic mercury in the present case was rather higher than that $(3 \cdot 0$ $7.0 \mu \mathrm{g} / \mathrm{g})$ of mercury workers and that $(0.9-1.5 \mu \mathrm{g} / \mathrm{g})$ of islanders of South Japan (Miyama et al., 1973). The mercury workers were living in Tokyo and exposed to an atmospheric concentration of mercury vapour around $0.1 \mathrm{mg} / \mathrm{m}^{3}$; their fish intake was not reported but was presumably in the usual range of city-dwellers. The islanders were everyday fisheaters. The level of organic mercury in this patient was higher than that $(3 \cdot 7-6 \cdot 6 \mu \mathrm{g} / \mathrm{g})$ of the mercury workers and comparable with that $(7 \cdot 4-11 \cdot 3 \mu \mathrm{g} / \mathrm{g})$ of the islanders.

\section{Discussion}

Selective effect of D-penicillamine

It is generally believed that the mechanism by which D-penicillamine effects metal excretion is that the $-\mathrm{SH}$ group of D-penicillamine reacts with metals and forms a penicillamine-metal complex. Walshe (1956) postulated that the metal had one bond connected to the sulphur and the other to the nitrogen of penicillamine, and that the metal was excreted as the complex. However, Suzuki and Yoshino (1969) pointed out that such a structure described by Walshe was impossible in the case of organic mercury. According to the hypothesis of Walshe, D-penicillamine should stimulate the urinary excretion of inorganic rather than organic mercury. But this is not the case in our results. 
Only one valency of mercuric ion $(\mathrm{Hg}++)$ was reported by Clarkson and Magos (1966) to react with binding sites in liver and kidneys. They also reported the remaining valency of $\mathrm{Hg}++$ being capable of forming a bond with penicillamine. In the case of organic mercury, there is one valency of free binding capacity with which organic mercury is bound to the binding site in tissues. The D-penicillamine molecule should compete for the one valency of organic mercury with the tissue binding sites and could form a penicillamine-organic mercury complex.

The reason why D-penicillamine enhances the urinary excretion of organic mercury selectively is not explained by the different nature of mercurypenicillamine complexes. Clarkson and Magos (1966) differentiated two classes of binding sites for mercury; the first was 100-fold greater than the second in the chemical affinity for mercury. On the relatively low dose level, it can be considered that most inorganic mercury binds the high affinity sites, and under such a condition D-penicillamine is not effective. By this hypothesis we can explain the ineffectiveness of D-penicillamine in the present results. But it is not known how organic mercury binds to the binding sites in the tissues. The present results suggest that binding is weaker than that of inorganic mercury. We need further experiments in which organic mercury is replaced by inorganic mercury, and inorganic mercury by organic mercury at the tissue binding sites.

Effectiveness of D-penicillamine versus time interval between end of exposure and its administration

As regards the total mercury, D-penicillamine did not affect the urinary excretion at the second trial in the present case but did at the first trial. The level of urinary total mercury at the second trial was interestingly similar to that in the case reported by Suzuki and Yoshino (1969) of the ineffectiveness of D-penicillamine. If they had carried out the selective measurements of inorganic and organic mercury, the enhancement of urinary mercury excretion might have been observed.

Elevated levels of organic mercury in urine and hair The levels of organic mercury in urine on the days without D-penicillamine were higher compared to those observed in persons without any particular exposure to mercurials (Suzuki and Shishido, 1974). Though the present authors did not measure the mercury content in the actual diet, it is unlikely that the elevated amount of organic mercury, especially at the first trial, came solely from contaminated food. We have to bear in mind here that only a small portion (less than $10 \%$ ) of ingested methylmercury is excreted in urine compared with a fairly high percentage of inorganic mercury (Ekman, Greitz,
Persson, and Åberg, 1968). If the daily dietary intake of fish is $100 \mathrm{~g}$ and its methylmercury content is $0.3 \mu \mathrm{g} / \mathrm{g}$ (the allowable limit for sale in the market by the Japanese Ministry of Health (1973)), the daily urinary excretion of methylmercury will not exceed $3 \mu \mathrm{g}$.

As for the origin of the elevated urinary organic mercury in this patient, it is natural to point first to the body store of organic mercury and the replacement of organic by inorganic mercury. In this connection, the organic mercury level in hair in this patient is important because it reflects to some extent the body store of organic mercury. The organic mercury level in hair was, as already mentioned, higher than that of urban mercury workers in Tokyo and comparable with that of islanders, but less than that $(20-40 \mu \mathrm{g} / \mathrm{g})$ reported in heavy fish eaters (Suzuki, 1971). The patient should have had a relatively large body store of organic mercury at the first trial of D-penicillamine administration.

We have not discussed the possibility of methylation of inorganic mercury in the body. If it occurred the body store of organic mercury would be increased as the natural sequence. Suzuki and Shishido (1974) found that the level of urinary organic mercury became higher with the increase of urinary inorganic mercury content in groups with varying degrees of inorganic mercury exposure. They also mentioned two possible mechanisms to explain their findings - the replacement of organic mercury and the methylation of inorganic mercury.

\section{References}

Aposhian, H. V. (1958). Protection by D-penicillamine against the lethal effects of mercuric chloride. Science, 128, 93.

Clarkson, T. W. and Magos, L. (1966). Studies on the binding of mercury in tissue homogenates. Biochemical Journal, 99, 62-70.

Ekman, L., Greitz, U., Persson, G., and Åberg, B. (1968). Metabolism and retention of methyl-203-mercurynitrate in man (in Swedish). Nordisk Medicin, 79, 450-456.

Japanese Ministry of Health (1973). Guidelines of regulations for mercury in fish (in Japanese). Koshu Eisei Joho, 3, 4-5.

Magos, L. (1971). Selective atomic-absorption determination of inorganic mercury and methylmercury in undigested biological samples. Analyst, 96, 847-853.

Miyama, T., Asakura, T., Takemoto, T., and Suzuki, T. (1973). Comparison of contents of inorganic and organic mercury between the extract with hydrochloric acid and the digested specimens by sodium hydroxide in human hair. Industrial Health, 11, 149-154.

Skerfving, S. (1974). Methylmercury exposure, mercury levels in blood and hair and health status in Swedes consuming contaminated fish. Toxicology, (in press). 
Smith, A. D. M. and Miller, J. W. (1961). Treatment of inorganic mercury poisoning with $\mathrm{N}$-acetyl-D,Lpenicillamine. Lancet, 1, 640-642.

Suzuki, T. (1971). Interaction of man and his environment in island ecosystems (in Japanese). Proceedings of XVIII Congress of Japan Medical Association (Tokyo), pp. $964-972$

- and Shishido, S. (1974). Changes of levels of urinary organic mercury in groups with varying extents of inorganic mercury exposure. Tohoku Journal of Experimental Medicine, 112, 101-102.

_ and Yoshino, Y. (1969). Effects of D-penicillamine on urinary excretion of mercury in two cases of methylmercury poisonings. Japanese Journal of Industrial Health, 11, 487-488.

Tsubaki, T. and Shirakawa, K. (1968). Treatment of organic mercury poisoning (in Japanese). Shinyaku to Rinsho, 15, 1471-1475.

Walshe, J. M. (1956). Penicillamine, a new oral therapy for Wilson's disease. American Journal of Medicine, 21, 487-495.

Received for publication 5 December 1973

Accepted for publication 9 January 1974

\title{
The April (1974) Issue
}

\author{
Mesothelioma Register 1967-68 M. Greenberg AND T. A. Lloyd Davies
}

Mortality and morbidity among the working population of anthophyllite asbestos miners in Finland L. O. Meurman, R. Kiviluoto, and M. Hakama

Renal ultrastructure, renal function, and parameters of lead toxicity in workers with different periods of lead exposure K. Cramér, R. A. Goyer, R. JAGenburg, and MARION H. Wilson

The pathology of experimental lead encephalopathy in the baboon (Papio anubis) A. P. HopkINS AND A. D. DAYAN

Excretion of cadmium through bile and intestinal wall in rats M. CIKRT AND M. TICHÝ

A survey of occupational cancer in the rubber and cablemaking industries: results of five-year analysis, 1967-71 A. J. Fox, D. C. Lindars, AND R. OWEN

Disability rates of bus drivers P. A. B. RAFFLE

Control of industrial exposure to tetrachloroethylene by measuring alveolar concentrations: theoretical approach using a mathematical model E. GUBERAN AND J. FerNANDEZ

Book reviews

Information section

A number of copies are still available and may be obatined from the Publishing Manager, British Medical Association, Tavistock Square, London WC1H 9JR, price $£ 1.25$ ( $£ 1.50$ in countries overseas; U.S.A. \$3.60). 